\title{
Ultraviolet radiation prevents bleaching in the Mediterranean coral Oculina patagonica
}

\author{
M. Fine ${ }^{1, *, * *}$, E. Banin ${ }^{2, *}$, T. Israely ${ }^{2}$, E. Rosenberg ${ }^{2}$, Y. Loya ${ }^{1}$ \\ ${ }^{1}$ Department of Zoology and ${ }^{2}$ Department of Molecular Microbiology and Biotechnology, \\ George S. Wise Faculty of Life Sciences, Tel Aviv University, Ramat Aviv 69978, Israel
}

\begin{abstract}
The causative agent of bleaching in the coral Oculina patagonica in the Mediterranean Sea is Vibrio shiloi. The bacterium becomes more virulent with increasing seawater temperature, resulting in extensive coral bleaching (80 to $90 \%$ ) every summer in 1 to $6 \mathrm{~m}$ depth. However, colonies in shallow water (0 to $80 \mathrm{~cm}$ depth) showed negligible bleaching, despite being exposed to higher temperatures $\left(\mathrm{ca} 2^{\circ} \mathrm{C}\right.$ ) than the deeper water corals. Fragments transplanted from $4 \mathrm{~m}$ depth to a shallow reef flat ( $<30 \mathrm{~cm}$ depth) in May showed no bleaching during the summer months, whereas intact colonies at $4 \mathrm{~m}$ and fragments transplanted to that depth from the reef flat underwent extensive bleaching. The concentration of $V$. shiloi was very high $\left(>2 \times 10^{4} \mathrm{~cm}^{-2}\right)$ in bleached fragments at $4 \mathrm{~m}$, whereas in non-bleached fragments from the reef flat, $V$. shiloi could not be detected. When $O$. patagonica was infected with $V$. shiloi in laboratory aquaria and subsequently exposed to sunlight, the intracellular bacteria were rapidly killed, aborting the infection and preventing bleaching. However, when the infected corals were protected from ultraviolet (UV) light, the intracellular $V$. shiloi multiplied and the coral bleached. We present here for the first time evidence for prevention of coral bacterial bleaching by UV radiation (UVR).
\end{abstract}

KEY WORDS: Corals · Oculina patagonica $\cdot$ Bleaching $\cdot$ UV $\cdot$ Vibrio shiloi $\cdot$ Mediterranean

\section{INTRODUCTION}

Coral bleaching, the disruption of the symbiotic association between coral hosts and their symbiotic photosynthetic algal endosymbionts, threatens coral reefs throughout the world (Hoegh-Guldberg 1999, Wilkinson et al. 1999). Coral bleaching is often linked to global climate change, especially elevated seawater temperature (Glynn 1991, 1993, Brown 1997, HoeghGuldberg 1999) and high solar irradiance (Jokiel 1980, Lesser et al. 1990, Gleason \& Wellington 1993, Glynn 1993). The latter is known to negatively affect photosynthesis, growth of zooxanthellae (Lesser \& Shick 1989) and survival of epifauna (Jokiel 1980, Siebeck 1988). Gleason \& Wellington (1993) transplanted

\footnotetext{
*The first 2 authors contributed equally to this research

${ }^{* *}$ E-mail: mfine@post.tau.ac.il
}

colonies of Montastrea annularis from $24 \mathrm{~m}$ to 18 and $12 \mathrm{~m}$, either exposing them to ambient irradiance or screening them from ultraviolet radiation (UVR, 280 to $400 \mathrm{~nm}$ ). They found that colonies transplanted to a shallower depth were paler and revealed lower densities of zooxanthellae compared with shielded colonies at the same depth, and concluded that it was the higher UVR that had affected the corals. This led to a series of studies on the effect of high UVR on cultured zooxanthellae (Banaszak \& Trench 1995, Lesser 1996) and dinoflagellates living within various cnidarian tissues (Lesser \& Shick 1989, Kinzie 1993, Banaszak \& Trench 1995). A range of anti-UVR protective mechanisms were demonstrated for the cnidirian host and symbiotic dinoflagellates including mycosporin-like amino acids (MAA), fluorescent pigments (Salih et al. 2000) and active oxygen scavenging systems (Shick et al. 1996). Although several investigators have suggested that elevated levels of UVR have been instru- 
mental in causing bleaching, field evidence for a primary role of UVR has been circumstantial (HoeghGuldberg 1999).

Bleaching of Oculina patagonica was first recorded along the Israeli coast in summer 1993 (Fine \& Loya 1995). Since then, 80 to $90 \%$ of coral colonies exhibit bleaching during the summer months when water temperature reaches a maximum of 29 to $30^{\circ} \mathrm{C}$, and then recover in the winter (Kushmaro et al. 1998). When analyzing a disease affected by environmental factors, it is critical to appreciate the difference between cause and causative agent. In the case of the coral O. patagonica in the Mediterranean, the causative agent for bleaching is the bacterium Vibrio shiloi (Kushmaro et al. 1996, 1997), whereas the environmental cause of the disease is increased seawater temperature (Kushmaro et al. 1998). The increased seawater temperature results in expression of virulence genes in the bacterium, leading to adhesion of the bacterium to a $\beta$-Dgalactoside receptor on the coral surface (Toren et al. 1998), penetration and multiplication of the bacterium in the coral tissue (Banin et al. 2000a,b), and production of toxins and killing of the intracellular algae (BenHaim et al. 1999, Rosenberg et al. 1999).

The initial observation that led to this study was the low level of coral bleaching in tidal pools and reef flats compared to corals in deeper water, despite higher surface seawater temperature (SST) in shallow waters. Experiments described here indicate that UV light in solar radiation kills Vibrio shiloi, which is present within the coral tissue, and aborts the infection and subsequent bleaching.

\section{MATERIAL AND METHODS}

Field experiments. We have been continuously monitoring bleaching of Oculina patagonica since 1993 (Kushmaro et al. 1998, Fine unpubl.). In the present study, we focused on bleaching of colonies inhabiting the reef flat $(<30 \mathrm{~cm}$ depth), very shallow tide pools (30 to $80 \mathrm{~cm}$ depth) and, for comparison, bleaching of colonies inhabiting depths of 1 to $6 \mathrm{~m}$. The study was carried out off the coast of Sdot-Yam, Israel. Monthly (June to December 2000) observations for percentage of bleaching were performed on 40 tagged colonies on the reef flat, 40 in tide pools and 200 at depths of 1 to $6 \mathrm{~m}$. Colonies that were visually estimated to exceed $10 \%$ bleached living surface area were scored as bleached colonies.

SST data at $6 \mathrm{~m}$ and in the tide pools were obtained using Onset Stow Away data-loggers (sampling once every hour).

To test the hypothesis that solar radiation may affect coral bleaching, 24 colonies at $4 \mathrm{~m}$ depth and 24 colonies on the reef flat were tagged during mid-May 2000, a few weeks before the seawater temperature rises abruptly and Oculina patagonica colonies undergo bleaching (Kushmaro et al. 1998). Two fragments from each colony were cored out using a stainless-steel corer $\left(\mathrm{r}=1.5 \mathrm{~cm}\right.$, fragment surface area $\left.=7.0 \mathrm{~cm}^{2}\right)$. One set of fragments was glued and tagged near their intact mother colony as controls and the second set of fragments was used for reciprocal transplantation between $4 \mathrm{~m}$ depth and the reef flat. The state of bleaching of the intact colonies and the fragments was monitored monthly. In August 2000, 8 transplanted core fragments from $4 \mathrm{~m}$ and 8 from the reef flat were collected and examined for presence of Vibrio shiloi using specific polyclonal antibodies (Banin et al. 2000b). Total counts and CFU (colony forming units) were performed using fluorescence microscopy and Marine agar (DIFCO), respectively.

Laboratory experiments. To test the hypothesis that solar radiation may protect corals from bacterialinduced bleaching, 40 fragments of healthy Oculina patagonica (each ca $3 \mathrm{~cm}^{2}$ ) were infected with $4.2 \times$ $10^{4}$ Vibrio shiloi $\mathrm{ml}^{-1}$ in a $2 \mathrm{l}$ aquarium. After $3 \mathrm{~d}$ in the laboratory aquarium under a 12:12 h light:dark regime, 20 of the infected fragments were placed in an aquarium in direct sunlight (+UV) while an additional 20 were placed in another aquarium in direct sunlight, but shielded from UVR (-UV) with a $5 \mathrm{~mm}$ Plexiglas cover which blocks $100 \%$ of UVR (280 to $400 \mathrm{~nm}$ ) but transmits $95 \%$ of the visible light (400 to $700 \mathrm{~nm})$. The average irradiation at $12: 00 \mathrm{~h}$ for UVA (320 to $400 \mathrm{~nm}$ ) and UVB (280 to $320 \mathrm{~nm}$ ) was 28.8 and $1.7 \mathrm{~J} \mathrm{~s}^{-1} \mathrm{~m}^{-2}$ respectively. Ten coral fragments (5 -UV and $5+\mathrm{UV}$ ), uninfected with $V$. shiloi, were cultured under the same conditions as control. The aquaria were aerated and maintained at $28 \pm 0.5^{\circ} \mathrm{C}$ in a water bath. At the indicated times, coral fragments were assayed for internal $V$. shiloi by the gentamycin invasion assay, using specific $V$. shiloi antibodies (Banin et al. 2000b).

\section{RESULTS}

\section{Field observations}

Bleaching of Oculina patagonica colonies was found to be depth dependent. The observed bleaching rate varied from an average of $3.6 \pm 1.5 \%(n=40)$ on the reef flat to $11.4 \pm 4 \%(\mathrm{n}=40)$ in the tide pools and up to an average of $84 \pm 10 \%(n=200)$ at a depth of 1 to $6 \mathrm{~m}$ (Fig. 1). The percentage of colonies undergoing bleaching increased dramatically at depths greater than $0.5 \mathrm{~m}$ (Fig. 1). No change in percentage of bleaching was detected between 1 and $6 \mathrm{~m}$ depth. 


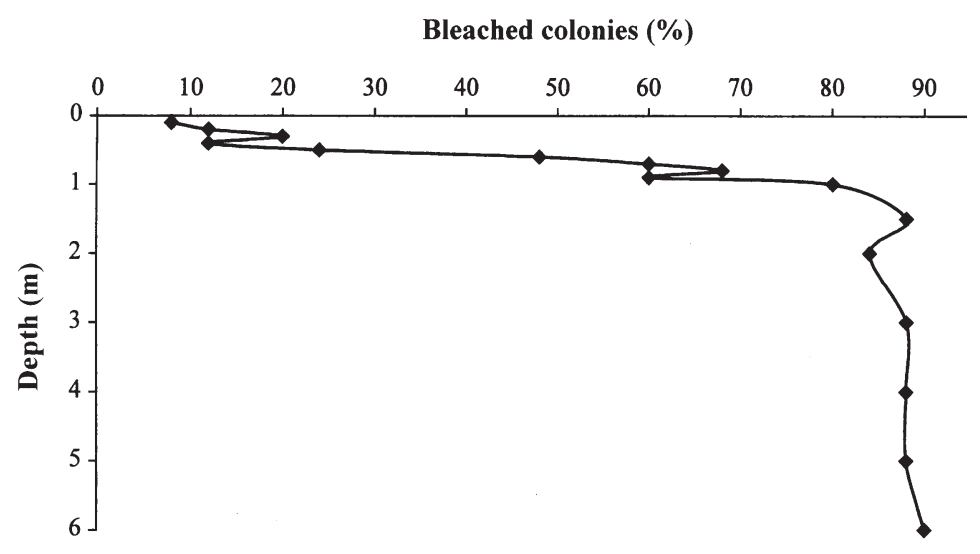

Fig. 1. Oculina patagonica. Bleaching along a depth gradient, from the reef flat $(<30 \mathrm{~cm}$ depth) down to tide pools $(30$ to $80 \mathrm{~cm})$ and at 1 to $6 \mathrm{~m}$

\section{Temperature data patterns}

As revealed from the temperature record retrieved from the data loggers at $6 \mathrm{~m}$ and in a tide pool (30 to $80 \mathrm{~cm}$ depth), in summer, during bleaching events (May to October), the monthly mean SST in shallow tide pools is ca $2^{\circ} \mathrm{C}$ higher than that at a depth of $6 \mathrm{~m}$ (Fig. 2A). From October to December, an opposite trend in SST was detected, with higher SST at a depth of $6 \mathrm{~m}$ compared with that in the tide pool. Furthermore, the daily amplitude in the tide pools is much wider (over $2^{\circ} \mathrm{C}$ ) than that at $6 \mathrm{~m} \mathrm{(ca} 0.5^{\circ} \mathrm{C}$ ) (Fig. 2B). Maximum temperature in tide pools and on the reef flat reached $32^{\circ} \mathrm{C}$ for a period of a few hours, whereas the temperature at the same time at $6 \mathrm{~m}$ depth was $28.5^{\circ} \mathrm{C}$ (Fig. 2B). The maximum daily temperature at $6 \mathrm{~m}$ during the summer months was lower than the minimum daily temperature in the tide pools (Fig. 2B).

\section{Transplantation experiment}

In the transplantation experiment, only $8 \%$ of the intact colonies $(n=24)$ on the reef flat showed negligible dimensions of bleaching (i.e. ca $5.0 \%$ of the colony's surface area appeared bleached, Fig. 3, a). The same result was obtained for the control fragments $(\mathrm{n}=$ 24) on the reef flat (Fig. 3, b). However, all Oculina patagonica fragments $(\mathrm{n}=$
24) transplanted from the reef flat to $4 \mathrm{~m}$ depth underwent substantial bleaching (100\% of the fragments) with an average bleached surface area of $32 \pm 23 \%$ (Fig. 3, c). At $4 \mathrm{~m}$ depth, $96 \%$ of the intact colonies and control fragments underwent bleaching, with a $35 \pm 25 \%$ bleached surface area in both cases (Fig. 3, d,e). In contrast, only $8 \%$ of the fragments transplanted from $4 \mathrm{~m}$ to the reef flat underwent negligible bleaching of ca $5 \%$ bleached surface area (Fig. 3, f).

Vibrio shiloi was not detected in any of the 8 non-bleached fragments transplanted from $4 \mathrm{~m}$ to the reef flat, whereas in the 8 bleached fragments transplanted from the reef flat to $4 \mathrm{~m}$ the total counts varied from $8 \times 10^{6}$ to $2 \times 10^{8}$ cells $\mathrm{cm}^{-2}$ of coral fragment (Table 1).
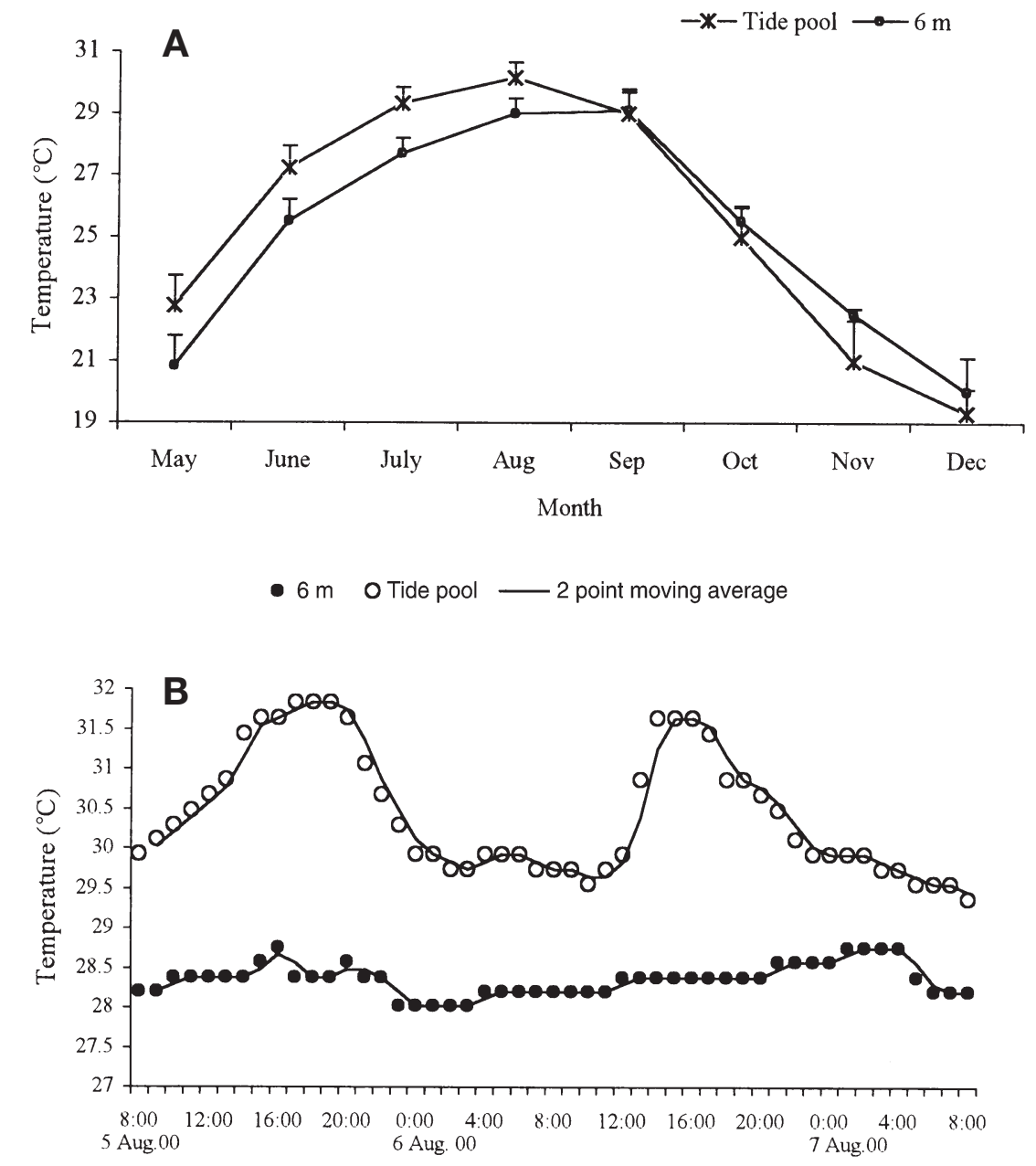

Fig. 2. Seawater temperature. (A) Monthly averages (May to December) in tide pools and at $6 \mathrm{~m}$ depth during the bleaching season of Oculina patagonica. (B) Daily temperature (sampled every h) in a tide pool and at $6 \mathrm{~m}$ depth during $48 \mathrm{~h}$ in August 2000. Data presented as 2 point moving average 


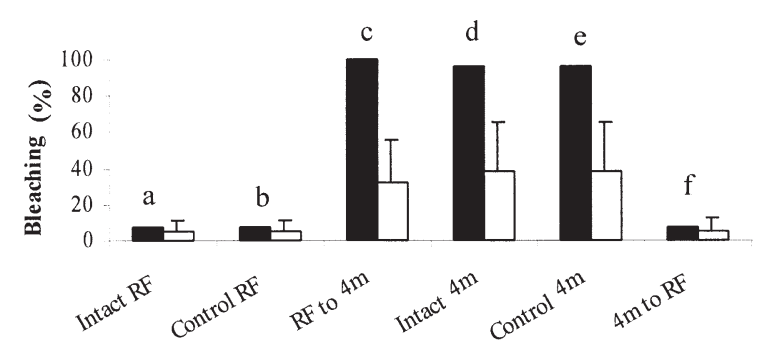

Fig. 3. Oculina patagonica. Percentage $( \pm \mathrm{SD})$ of bleached colonies (black bars) and bleached living surface area (blank bars) of intact colonies $(\mathrm{a}, \mathrm{d})$ and fragments transplanted to the reef flat (RF, f) and to $4 \mathrm{~m}$ depth (c), and control fragments (b, e)

\section{Aquarium experiments}

In the laboratory aquarium experiments, none of the 20 fragments of healthy Oculina patagonica infected with $4.2 \times 10^{4}$ Vibrio shiloi $\mathrm{ml}^{-1}$ and subsequently exposed to direct sunlight (+UV) showed any signs of bleaching (Fig. 4). In contrast, the 20 fragments infected with $V$. shiloi and exposed to direct sunlight but shielded from UV (-UV) showed a total loss of pigmentation after $10 \mathrm{~d}$, the hallmark of the bleaching disease. Uninfected control fragments exposed to sunlight under the same conditions showed no bleaching, regardless of whether or not they were covered with Plexiglas (Fig. 4). After $8 \mathrm{~h}$ exposure to unfiltered solar radiation, the number of $V$. shiloi per coral had

Table 1. Colony forming unit (CFU) and total counts of Vibrio shiloi in core fragments of Oculina patagonica after transplantation. $\mathrm{B}=$ bleached, $\mathrm{NB}=$ non-bleached

\begin{tabular}{|lccc|}
\hline Sample $^{\text {a }}$ & $\begin{array}{c}\text { Visual } \\
\text { observation }\end{array}$ & $\begin{array}{c}\text { CFU } \\
\left(\mathrm{cm}^{2}\right)\end{array}$ & $\begin{array}{c}\text { Total count } \\
\left(\mathrm{cm}^{2}\right)\end{array}$ \\
\hline 1 & $\mathrm{~B}$ & $2 \times 10^{5}$ & $\begin{array}{c}\text { Not detected } \\
2\end{array}$ \\
3 & $\mathrm{~B}$ & $3.5 \times 10^{5}$ & $1.1 \times 10^{8}$ \\
4 & $\mathrm{~B}$ & $2 \times 10^{4}$ & $8 \times 10^{6}$ \\
5 & $\mathrm{~B}$ & $2 \times 10^{4}$ & $8 \times 10^{7}$ \\
6 & $\mathrm{~B}$ & $4 \times 10^{5}$ & $2 \times 10^{8}$ \\
7 & $\mathrm{~B}$ & $5 \times 10^{5}$ & $1 \times 10^{7}$ \\
8 & $\mathrm{~B}$ & $3 \times 10^{4}$ & $3 \times 10^{7}$ \\
9 & $\mathrm{~B}$ & $1 \times 10^{6}$ & $8 \times 10^{7}$ \\
10 & NB & Not detected & Not detected \\
11 & NB & Not detected & Not detected \\
12 & NB & Not detected & Not detected \\
13 & NB & Not detected & Not detected \\
14 & NB & Not detected & Not detected \\
15 & NB & Not detected & Not detected \\
16 & NB & Not detected & Not detected \\
asamples 1 to 8 are cores transplanted from the reef flat to \\
4 m depth. Samples 9 to 16 are cores transplanted from \\
4 m to the reef flat & & \\
\hline
\end{tabular}

decreased by $97 \%$ to $6 \times 10^{5} \mathrm{~cm}^{-2}$ coral fragment (Fig. 5). After $10 \mathrm{~h}$, they were no longer detectable (i.e. $<10^{5}$ ). In the aquarium protected from UV light, the number of $V$. shiloi inside the coral increased to 2.5 $\times 10^{7}$ per coral after $6 \mathrm{~h}$ and then remained relatively constant for at least $1 \mathrm{wk}$ (Fig. 5). A comparison of the rate of UV killing of $V$. shiloi in the coral epidermis compared to that in seawater (data not presented) at the same depth $(30 \mathrm{~cm})$ indicated that the coral provided little, if any, protection to the pathogenic bacteria.

\section{DISCUSSION}

In the present study, we clearly demonstrate that in Oculina patagonica along the Mediterranean coast of Israel, UVR prevents bleaching. This is at variance with previous reports that UVR may be one of the causes of coral bleaching (Jokiel 1980, Lesser et al. 1990, Gleason \& Wellington 1993, Glynn 1993). Most evidence indicates that elevated temperature is the major cause of mass bleaching events (Hoegh-Guldberg 1999). The cause for bleaching of O. patagonica in the Mediterranean is also temperature (Kushmaro et al. 1998). Moreover, while 80 to $90 \%$ of O.patagonica colonies undergo bleaching during the summer months in the eastern Mediterranean, no bleaching of that species has ever been recorded in the western Mediterranean (Fine 2001), where summer temperatures are much lower $\left(<22^{\circ} \mathrm{C}\right)$. Kushmaro et al. (1998) demonstrated that colonies exposed to a temperature of $29^{\circ} \mathrm{C}$ did not bleach if the causative bleaching pathogen was not present, whereas bleaching occurred slowly at $20^{\circ} \mathrm{C}$ and rapidly at $29^{\circ} \mathrm{C}$ in the presence of the pathogen.

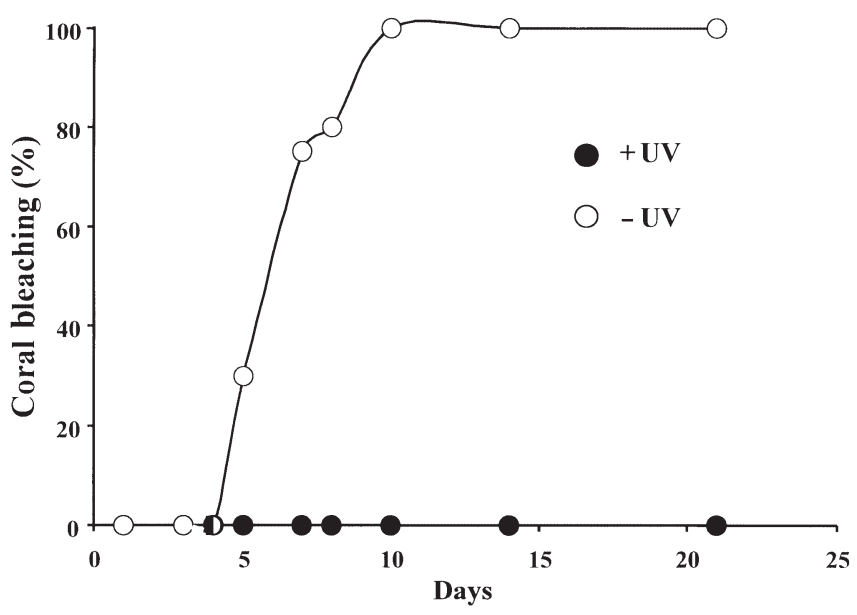

Fig. 4. Oculina patagonica. Effect of solar radiation on the bleaching of the coral by the pathogenic bacteria Vibrio shiloi 


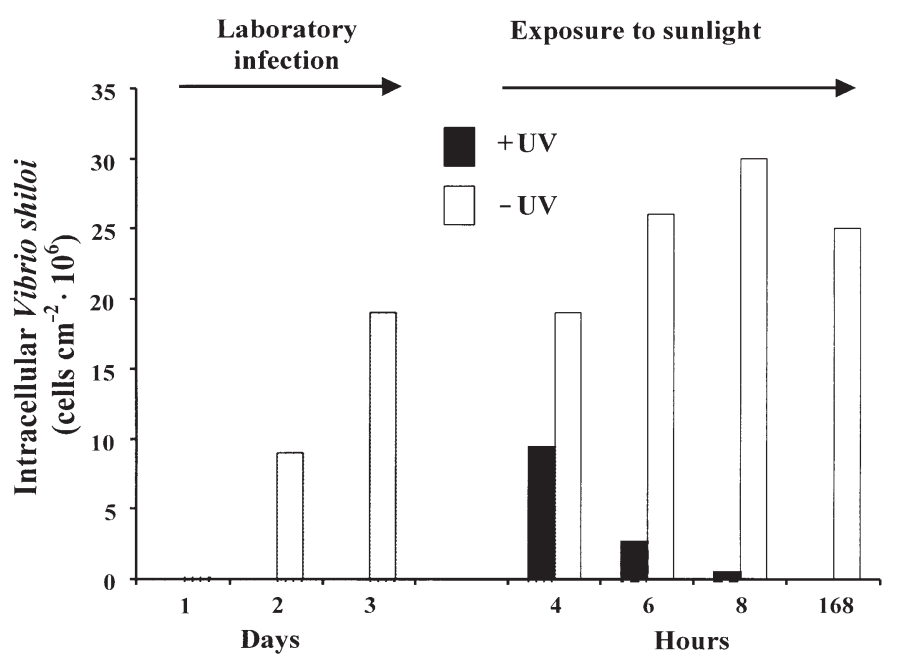

Fig. 5. Oculina patagonica. Effect of solar radiation on Vibrio shiloi inside the coral host ectodermis as determined by fluorescence microscopy

Toren et al. (1998) demonstrated that bleaching of Oculina patagonica is temperature regulated via production of the adhesin required for adhesion of Vibrio shiloi to its host coral. Accordingly, at higher temperatures, bacterial synthesis of the adhesin results in efficient adhesion to the coral and subsequently high bleaching. At winter temperatures $\left(16^{\circ} \mathrm{C}\right)$ the adhesin is not produced by the bacterium and no infection takes place. In addition to adhesion, intracellular growth of the bacteria and toxin production are also temperature dependent (Banin et al. 2000a,b).

According to the data retrieved from the temperature data loggers at $6 \mathrm{~m}$ and in tide pools $(<80 \mathrm{~cm})$, temperature at shallower depths is ca $2^{\circ} \mathrm{C}$ warmer than at $6 \mathrm{~m}$ during the summer months (Fig. 2A). The temperature on the reef flat and tide pools is greatly influenced by tide cycle and amplitude; hence, on a daily scale, Oculina patagonica colonies in tide pools experience temperatures $4^{\circ} \mathrm{C}$ above that at $6 \mathrm{~m}$ (especially during low tide) for a period of several hours (Fig. 2B). Even at high tide when temperature in the shallows approaches that at $6 \mathrm{~m}$, the latter will still be ca $1^{\circ} \mathrm{C}$ colder (Fig. 2B). Thus, a much higher bleaching percentage would be expected in these warmer shallows than at $6 \mathrm{~m}$. Ironically, the opposite is true. As revealed in the present study, colonies of $O$. patagonica inhabiting the reef flat exposed to high water temperature and irradiance underwent a much lower bleaching rate than colonies at a depth of 1 to $6 \mathrm{~m}$ (Fig. 1).

Brown et al. (2000) provided data on the bleaching pattern of Goniastrea aspera, a shallow-water IndoPacific coral. They reported that corals exposed to high solar radiation prior to maximum seawater temperature were protected from bleaching. They explain their data by suggesting that 'experience can shape coral bleaching patterns.' More specifically, they state that exposure to high solar radiation caused the corals to become more tolerant to the combined stress of temperature and solar radiation. Similar observations were reported by Loya et al. (2001) at Sesoko Island, Japan, where juvenile Acropora colonies in the intertidal zone survived bleaching events despite being exposed to high irradiance during summer midday low tides. This survival is especially intriguing in view of the mass mortality observed in coral colonies of the same species in deeper water of the same locality. The data presented in this paper suggest a novel testable hypothesis, i.e. the reason some coral species do not bleach under high solar irradiance may be because coralbleaching bacteria are destroyed under such conditions.

Due to the possibility that corals present in shallower water intrinsically differ from deeper water corals (i.e. may contain different clades of zooxanthellae), the transplantation experiment was performed. When fragments of Oculina patagonica colonies were transplanted from $4 \mathrm{~m}$ depth to the reef flat, they did not bleach, although their intact mother colony did (Fig. 3). Consistent with the visual observations on bleaching were the low numbers of the causative bleaching agent Vibrio shiloi detected in transplanted fragments from $4 \mathrm{~m}$ to the reef flat (Table 1). All the data support the contention that in the case of O. patagonica, UVR is lethal to the causative agent of bleaching.

Lyons et al. (1998) reported that bacteria in the surface microlayer of the coral Montastrea faveolata receive some protection from UVR. In the case of Vibrio shiloi in Oculina patagonica, in order to achieve successful colonization the bacteria must multiply at a rate higher than their elimination by solar radiation. Since the doubling time of $V$. shiloi in O. patagonica at $28^{\circ} \mathrm{C}$ is ca $6 \mathrm{~h}$ (Kushmaro et al. 1997), for $V$. shiloi to bleach $O$. patagonica, the coral must be at a depth where UVR is low enough to enable a half-life of the bacterium to exceed $6 \mathrm{~h}$. In the Mediterranean Sea off the coast of Israel in the summer, this would correspond to a depth of ca $1 \mathrm{~m}$.

Salih et al. (2000) reported a protective mechanism in which fluorescent pigments (FPs) serve as sunscreens and enhance the resistance of corals to bleaching during periods of heat stress. Coral colonies in shallower water, exposed to higher solar radiation, were much more reflective due to higher concentrations of FPs (Salih et al. 2000). Fluorescent pigments may be one of the mechanisms allowing Oculina patagonica and its endosymbionts to inhabit reef flats and survive the high intensity solar radiation. However, because bacteria are haploid and generally highly sensitive to UVR, much more so than algae or 
corals, high solar radiation kills the pathogen and thereby prevents bleaching.

The healing effect of UV on diseases caused by pathogenic bacteria is known in other systems. Liltved \& Landfald (2000) reported that viability of fish pathogenic bacteria was rapidly reduced when exposed to sunlight. A 99.9\% inactivation was observed after $2 \mathrm{~h}$ exposure. The variable effect of UV on marine bacteria has also been reported by Joux et al. (1999). Clearly, more research is necessary before generalizing on the effect of UV on the possible prevention of coral diseases and their general health.

Acknowledgements. We thank E. Orr for the polyclonal antibodies and A. Kudish for the UVR data. This work was supported by the Raynor Chair for Environmental Conservation Research to Y.L., and the Israel Center for Emerging Diseases and the Pasha Gol Chair for Applied Microbiology to E.R.

\section{LITERATURE CITED}

Banaszak AT, Trench RK (1995) Effects of ultraviolet (UV) radiation on marine microalgal-invertebrate symbioses. I. Response of the algal symbionts in culture and in hospite. J Exp Mar Biol Ecol 194:213-232

Banin E, Ben-Haim Y, Israely T, Loya Y, Rosenberg E (2000a) Effect of the environment on the bacterial bleaching of corals. Water Air Soil Pollut 123:337-352

Banin E, Israely T, Kushmaro A, Loya Y, Orr E, Rosenberg E (2000b) Penetration of the coral-bleaching bacterium Vibrio shiloi into Oculina patagonica. Appl Environ Microbiol 66:3031-3036

Ben-Haim Y, Banin E, Kushmaro A, Loya Y, Rosenberg E (1999) Inhibition of photosynthesis and bleaching of zooxanthellae by the coral pathogen Vibrio shiloi. Environ Microbiol 1:223-229

Brown BE (1997) Coral bleaching: causes and consequences. Coral Reefs 16:129-138

Brown BE, Dunne RP, Goodson MS, Douglas AE (2000) Bleaching patterns in reef corals. Nature 404:142-143

Fine M, Loya Y (1995) The coral Oculina patagonica a new immigrant to the Mediterranean coast of Israel. Isr J Zool 41:84

Fine M, Zibrowius H, Loya Y (2001) Oculina patagonica: a non lessepsian scleractinian coral invading the Mediterranean Sea. Mar Biol 138:1195-1203

Gleason DF, Wellington GM (1993) Ultraviolet-radiation and coral bleaching. Nature 365:836-838

Glynn PW (1991) Coral-reef bleaching in the 1980s and possible connections with global warming. TREE 6:175-179

Glynn PW (1993) Coral-reef bleaching-ecological perspectives. Coral Reefs 12:1-17

Hoegh-Guldberg O (1999) Climate change, coral bleaching and the future of the world's coral reefs. Mar Freshw Res 50:839-866

Jokiel PL (1980) Solar ultraviolet radiation and coral reef epi-

Editorial responsibility: Otto Kinne (Editor),

Oldendorf/Luhe, Germany fauna. Science 207:1069-1071

Joux F, Jeffrey WH, Lebaron P, Mitchell DL (1999) Marine bacterial isolates display diverse responses to UV-B radiation. Appl Environ Microbiol 65:3820-3827

Kinzie RA (1993) Effects of ambient levels of solar ultraviolet radiation on zooxanthellae and photosynthesis of the reef coral Montipora verrucosa. Mar Biol 116:319-327

Kushmaro A, Loya Y, Fine M, Rosenberg E (1996) Bacterial infection and coral bleaching. Nature 380:396

Kushmaro A, Rosenberg E, Fine M, Loya Y (1997) Bleaching of the coral Oculina patagonica by Vibrio AK-1. Mar Ecol Prog Ser 147:159-165

Kushmaro A, Rosenberg E, Fine M, Ben-Haim Y, Loya Y (1998) Effect of temperature on bleaching of the coral Oculina patagonica by Vibrio AK-1. Mar Ecol Prog Ser 171:131-137

Lesser MP (1996) Elevated temperature and ultraviolet radiation cause oxidative stress and inhibit photosynthesis in symbiotic dinoflagellates. Limnol Oceanogr 41:271-283

Lesser MP, Shick JM (1989) Effects of irradiance and ultraviolet radiation on photoadaptation in the zooxanthellae of Aiptasia pallida: primary production, photoinhibition and enzymic defences against oxygen toxicity. Mar Biol 102: 243-255

Lesser MP, Stochaj WR, Tapley DW, Shick JM (1990) Bleaching in coral-reef anthozoans - effects of irradiance, ultraviolet-radiation, and temperature on the activities of protective enzymes against active oxygen. Coral Reefs 8: $225-232$

Liltved H, Landfald B (2000) Effects of high intensity light on ultraviolet-irradiated and non-irradiated fish pathogenic bacteria. Water Res 34:481-486

Loya Y, Sakai K, Yamazato K, Nakano Y, Sambli H, van Woesik R (2001) Coral bleaching: the winners and the losers. Ecol Lett 4:122-131

Lyons MM, Aas P, Pakulski JD, Van Waasbergen L, Miller RV, Mitchell DL, Jeffrey WH (1998) DNA damage induced by ultraviolet radiation in coral-reef microbial communities. Mar Biol 130:537-543

Rosenberg E, Ben-Haim Y, Toren A, Banin E, Fine M, Loya Y (1999) Effect of temperature on bacterial bleaching of corals. In: Rosenberg E (ed) Microbial ecology and infectious disease. ASM Press, Washington, DC, p 242-254

Salih A, Larkum A, Cox G, Kühl M, Hoegh-Guldberg O (2000) Fluorescent pigments in corals are photoprotective. Nature 408:850-853

Shick JM, Lesser MP, Jokiel PL (1996) Ultraviolet radiation and coral stress. Global Change Biol 2:527-545

Siebeck O (1988) Experimental investigation of UV tolerance in hermatypic corals (Scleractinia). Mar Ecol Prog Ser 43: 95-103

Toren A, Landau L, Kushmaro A, Loya Y, Rosenberg E (1998) Effect of temperature on adhesion of Vibrio strain AK-1 to Oculina patagonica and on coral bleaching. Appl Environ Microbiol 64:1379-1384

Wilkinson C, Linden O, Cesar H, Hodgson G, Rubens J, Strong AE (1999) Ecological and socioeconomic impacts of 1998 coral mortality in the Indian Ocean: an ENSO impact and a warning of future change? Ambio 28:188-196

Submitted: January 29, 2001, Accepted: June 14, 2001

Proofs received from author(s): January 15, 2002 